\title{
Tourist development and foreign immigration in Balearic Islands
}

Pere A. Salvà-Tomàs

\section{(2) OpenEdition \\ 12 Journals}

Édition électronique

URL : https://journals.openedition.org/remi/1686

DOI : $10.4000 /$ remi.1686

ISSN : $1777-5418$

Éditeur

Université de Poitiers

\section{Édition imprimée}

Date de publication : 1 mars 2002

Pagination : 87-101

ISBN : 2-911627-30-X

ISSN : 0765-0752

\section{Référence électronique}

Pere A. Salvà-Tomàs, "Tourist development and foreign immigration in Balearic Islands », Revue européenne des migrations internationales [En ligne], vol. $18-n^{\circ} 1$ | 2002, mis en ligne le 09 juin 2006 , consulté le 16 avril 2022. URL : http://journals.openedition.org/remi/1686 ; DOI : https://doi.org/ 10.4000/remi. 1686

Ce document a été généré automatiquement le 16 avril 2022.

(c) Université de Poitiers 


\title{
Tourist development and foreign immigration in Balearic Islands
}

\author{
Pere A. Salvà-Tomàs
}

1 At the threshold of the $21^{\text {th }}$ Century, the society of the Balearic Islands presents a complex composition. This is the result of the changes that have taken place since the 1950's and the irruption of mass tourism. The spectacular development of the tourist phenomenon in the Balearic Islands has held an important role in the changes in the geo-demography, socio-cultural and territorial characteristics of the Balearic Islands. The Islands have passed from a tourist affluence of 400000 tourists and 4,8 million stays in 1960 to 11,2 million tourists and more than 116 million stays in 2000. From its beginnings, tourism, as factor of manpower demand, caused important changes in the tendencies and direction of the migratory movements registered thus far in the Balearic Islands.

Migratory movements at different stages of mass tourism development

2 The interrelation between tourism development and migratory phenomena has impacted the Balearic Islands, creating an important flow of immigration whose forms, characteristics and geographical origin have changed significantly over the last forty years. In diagram 1 we can observe a synthesis of these changes at the different phases of the development of tourism in the Balearic Islands. 
Table 1 : The Migratory Movements in the stage of the Mass Tourism Development, 1950-2000

\begin{tabular}{|c|c|c|}
\hline Period & $\begin{array}{l}\text { Stadium of the } \\
\text { Tourist Development }\end{array}$ & $\begin{array}{l}\text { Characteristics of the Migratory } \\
\text { Movement }\end{array}$ \\
\hline $1950-1960$ & $\begin{array}{l}\text { Beginning and take off } \\
\text { of the Mass Tourism }\end{array}$ & $\begin{array}{l}\text { Intra-insular and inter-insular geographical mobility } \\
\text { type } \\
\text { - Insular interior migrations from rural areas to } \\
\text { tourist and/or urban areas. } \\
\text { - Rural exodus. } \\
\text { - Inter-insular and intra-insular migratory } \\
\text { movements (From Menorca and Pitiusas to } \\
\text { Mallorca) }\end{array}$ \\
\hline From 1960 & $\begin{array}{l}\text { Growth of the Mass } \\
\text { Tourism }\end{array}$ & $\begin{array}{l}\text { - Immigratory Movements of Spanish peninsula } \\
\text { origin. Rural exodus from Spanish depressed } \\
\text { rural areas to economic dynamic areas. } \\
\text { - Incidence about the growth of the population } \\
\text { and rejuvenation }\end{array}$ \\
\hline From 1970 & $\begin{array}{l}\text { Consolidation of the } \\
\text { Mass Tourism }\end{array}$ & $\begin{array}{l}\text { - Continuation of the immigratory peninsular } \\
\text { flows } \\
\text { - First phase of the residential immigration of } \\
\text { foreign origin }\end{array}$ \\
\hline From 1990 & $\begin{array}{l}\text { Maturity of the Mass } \\
\text { Tourism }\end{array}$ & $\begin{array}{l}\text { - Reactivation of the peninsular immigration of } \\
\text { urban and qualified type } \\
\text { - Growth of the residential immigration North- } \\
\text { South } \\
\text { - Increase of the labour immigration of North to } \\
\text { South (European origin) } \\
\text { - Increase of the labour immigration of South- } \\
\text { North of irregular and not qualified type. Latin } \\
\text { American and African immigration. }\end{array}$ \\
\hline
\end{tabular}

3 Until 1955, the Balearic Islands presented an emigratory situation. From this date, a new immigratory situation took hold and it has continued to develop up to the present time.

4 Knowledge of the Balearic Islands, tourism promotion and the potential of the labour market have led to the progressive arrival of immigrants of foreign origin since the 1970's. The first type of immigration was residential and later, in the 1980's, immigration became labour-related and/or entrepreneurial. From 1970, jointly with the acceleration of the immigrations of Spanish peninsular origin, the first foreign immigrants appear whose basic motivation was to establish residence, not to find labour. This first phase of foreign immigration, composed mainly of citizens of British origin, was made up of artists, retired persons and/or pensioners seeking tranquillity and quality of life. To those were added other foreigners of high economic level from Iranian and Latin American origin that settled later in residential estates with attractive landscapes. This migratory phenomenon grew largely into the 80's. On the one hand, there was an intensified flow of labour-based migration from diverse Latin American countries. On the other hand, the presence of foreign residential-type immigration (basically creating a compound for European citizens) increased. In this way, in the 1990's, the Balearic Islands became one of the most important destinations of European North-South flows of foreign immigration. During this period, foreign immigration (especially of German and British origin) related to residential tourism of long duration was predominant in the Balearic Islands. These migrants use the territory of the Balearic Islands as a permanent and/or seasonal residential space. The Balearic Islands can thus be considered as the urban periphery of the main European cities. 
The idealisation of the Mediterranean lifestyle and the potentiality of its labour market have made the Balearic Islands a territory with high residential attractiveness for a large number of foreign people. One fourth of these migrants forms a population of people over 60 years old that uses the Balearic Islands as a residential refuge in which to spend the last years of its life. This residential migration phenomenon that increased significantly starting in the 1970 's, formed a majority until the 1990's. It was mainly characterised by a retirement migration phenomenon. This first phase can be defined as a «New Florida " type phenomenon (Rodríguez, Salvà, Williams, 2001) since it is based on a residential model for ageing residents, similar to the situation observed in Florida (United States). In the case of Florida, in-migration was composed of retired persons whose motivation was to find spaces in the American sunbelt for leisure time and rest. Recently, in the Balearic Islands, this residential immigrant community has reduced its proportional weight because of an important increase in labour-motivated immigration of European origin as well as the South-North flow coming from African, Latin American and Asian countries. This new situation allows the Balearic Islands to be considered as a laboratory of analysis of a "New California " type processes. The argument for this consideration is based on the change from a residential migratory model based on consumption in the "New Florida" phase, to a new model characterised, at the present time, by a space of high economic growth and job increase and high dynamism in investments and technological innovation (Rodríguez, Salvà, Williams, 2001). Variables based on the new tourism conception appear like those of an industry of advanced services. These factors have caused a high demand of qualified technical, executive and management workforce while at the same time the Balearic Islands forms a space with a deficit of manpower in less qualified occupations. From this perspective we can establish similarities with the American region of California based on technological variables, resource consumption problems (electric energy, potable water, and waste elimination problems), population growth (based on the proportion of immigration in the absolute growth of the population), the coexistence of a dual migratory model (labour and residential migration; qualified and unqualified migration) and the demand for similar residential land use types (residential spaces for a retirement migration and residents' leisure).

6 The result, thus far, of the different phases of installation, take off and consolidation of mass tourism in the Balearic Islands is the current range of categories in the resident population (pre-tourist autochthonous population; immigrant population of Spanish peninsular origin; foreign immigrant population). These categories are the result of the different migratory flows that have arrived to the Balearic Islands over the last 40 years. This configuration implies the spatial and seasonal coexistence of these different groups, along with the pre-tourist population. It is therefore a multidimensional and diverse phenomenon, composed by currents and varied flows that imply differential effects.

Demographic characteristics of foreign residents

7 The evaluation of the real numbers of this foreign immigration to the Balearic Islands presents difficulties due to the high mobility of the population and the problems associated with information provided in official statistics. Official statistics only register census-registered residents and/or those that dispose of different types of legal residence and/or work permits. However, the large number of foreigners who are 
not formally registered and / or those that live during long seasons in the Balearic Islands with stays superior to three months do not appear in official statistics.

8 We denominate those in the first case permanent residents. The evaluation of their number was carried out, according to the upgrade of the population censuses (padrones - census / electoral register) and the annual mean data on foreigners who dispose of different types of work and/or residence permits granted by the Spanish public administration.

9 The second group, that we denominate seasonal residents, has been evaluated through a complex ensemble of indirect sources. We highlight among these:

10 - Sounding the issuing of aeroplane tickets from different airline companies operating in the Balearic Islands.

11 - Data of city-planning licenses on rural land granted to foreign citizens.

12 - Catastro de Bienes de Naturaleza Urbana en Suelo Rústico (Cadastre of Goods of Urban Nature in Rustic Land).

13 - Receipts of waste collection tax.

14 - Vehicle circulation tax.

15 - Registered users of electric power.

16 - Polling of the municipal city-planning services.

17 - Information from the municipal police and employees of the postal services.

18 - Social services information (irregular immigration).

19 According to these sources, 82246 foreign permanent residents with a legal situation were living in the Balearic Islands in June 2000. The global figure of foreign residents in the Balearic Islands increases dramatically if seasonal residents with stays superior to three months are added. The evaluation of their number in the 2001 sample reached a total of seasonal residents that surpasses 78000 foreigners. The sum of both categories represents a global figure that approaches 160000 foreign residents (table 2). 
Table 2: Foreign residents in the Balearic Islands. June 2001

\begin{tabular}{|c|c|c|c|c|c|}
\hline Continent & Nationality & Permanent & Seasonal & Total & $\begin{array}{l}\text { \% of foreigner } \\
\text { residents }\end{array}$ \\
\hline Europe & $\begin{array}{l}\text { German } \\
\text { British } \\
\text { French } \\
\text { Italian } \\
\text { Dutch } \\
\text { Swiss } \\
\text { Swedish } \\
\text { Belgian } \\
\text { Others }\end{array}$ & $\begin{array}{|rr|} & 50049 \\
18 & 876 \\
11 & 432 \\
4 & 948 \\
3 & 595 \\
1 & 804 \\
1 & 078 \\
1 & 102 \\
1 & 316 \\
5 & 898\end{array}$ & \begin{tabular}{|c|}
\multicolumn{1}{|c|}{55693} \\
39293 \\
11503 \\
813 \\
493 \\
467 \\
615 \\
167 \\
324 \\
2018 \\
\end{tabular} & 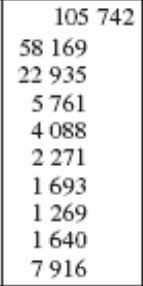 & $\begin{array}{r}36,3 \\
14,3 \\
3,6 \\
2,6 \\
1,4 \\
1,1 \\
1,0 \\
0,8 \\
4,9\end{array}$ \\
\hline Africa & $\begin{array}{l}\text { Moroccan } \\
\text { Senegalese } \\
\text { Algerian } \\
\text { Others }\end{array}$ & $\begin{aligned} & 11908 \\
& 8520 \\
& 897 \\
& 658 \\
& 1833 \\
&\end{aligned}$ & \begin{tabular}{|l|}
\multicolumn{1}{|c|}{16848} \\
8999 \\
4401 \\
2405 \\
1043 \\
\end{tabular} & \begin{aligned} \multicolumn{1}{|c|}{28756} \\
17519 \\
5298 \\
3063 \\
2876 \\
\end{aligned} & $\begin{array}{r}10,9 \\
3,3 \\
1,9 \\
1,8 \\
\end{array}$ \\
\hline Latin America & $\begin{array}{l}\text { Ecuadorian } \\
\text { Colombian } \\
\text { Argentinean } \\
\text { Cuban } \\
\text { Dominican } \\
\text { Chilean } \\
\text { Brazilian } \\
\text { Peruvian } \\
\text { Uruguayan } \\
\text { Venezuelan } \\
\text { Others }\end{array}$ & \begin{aligned} \multicolumn{1}{c}{16675} \\
4167 \\
3693 \\
3307 \\
1146 \\
753 \\
822 \\
692 \\
275 \\
636 \\
278 \\
906\end{aligned} & \begin{tabular}{|l|}
\multicolumn{1}{c|}{4529} \\
605 \\
334 \\
334 \\
381 \\
571 \\
200 \\
232 \\
132 \\
132 \\
100 \\
1508
\end{tabular} & \begin{tabular}{|r|}
\multicolumn{2}{|c|}{21204} \\
4772 \\
4027 \\
3641 \\
1527 \\
1324 \\
1022 \\
924 \\
768 \\
745 \\
378 \\
2076
\end{tabular} & $\begin{array}{l}3,0 \\
2,5 \\
2,3 \\
1,0 \\
0,8 \\
0,6 \\
0,6 \\
0,5 \\
0,5 \\
0,2 \\
1,3\end{array}$ \\
\hline Asia & & 2691 & 892 & 3583 & 2,2 \\
\hline Northern America & & 923 & 96 & 1019 & 0,6 \\
\hline Total & & 82246 & 78058 & 160304 & 100,0 \\
\hline
\end{tabular}

Source: Instituto Nacional de Estadística, Institut Balear d'Estadistica, Salvà-Tomàs.

The predominant presence of Europeans represents $66 \%$ of the total number of foreigners, which demonstrates the preference of the European population that considers the Balearic Islands as one of its more desired residential destinations. In percentage terms, this index has experienced a decrease in regard to previous years (Salvà 1996, 1998) because of the increase in African and Latin-American immigrant flow that has registered important growth since 1996. Currently, African migrants represent $18 \%$ of the total foreign population. This South-North flow of immigrants has displaced the traditional presence of immigrants of Latin American origin that have come to represent $13 \%$ of the total foreign population.

In terms of nationalities (fig. 1) the index highlights the clear prevalence of Germans who represent $36 \%$ of foreigners and $55 \%$ of the Europeans present. Their numbers have experienced significant growth since 1986, a factor that has opened a debate on their territorial, social and cultural incidence in the Balearic Islands. Their ongoing territorial preference is more marked on Mallorca Island where $75 \%$ of its total is concentrated. In second place, it appears that the British have experienced a significant percentage regression. They currently represent $22 \%$ of the total number of foreign residents. Their presence is predominant in the Menorca, Eivissa and Formentera Islands. In third place appear the Moroccans, representing $11 \%$ of the total number of foreign residents and $61 \%$ of the Africans. 
Figure 1 : Foreign residents by countries. Balearic Islands. June 2001

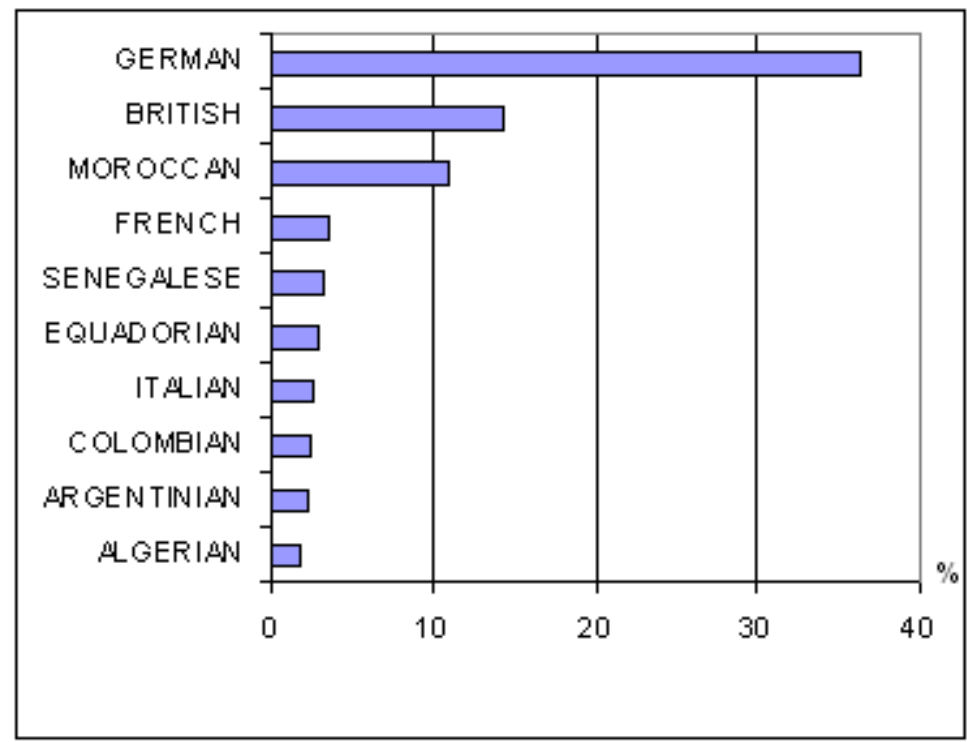

Effectif : 129273 personnes, soit 80,6 \% du total des étrangers

Source : Instituto Nacional de Estadística, Institut Balear d'Estadistica, Salvà-Tomàs

The index of the presence of foreigners (number of foreigners out of total inhabitants) is 0,22 . The percentage of foreign residents in the total population, calculated at 868 000 inhabitants at the end of 2001 , is to the order of $18,4 \%$.

The sex distribution sample indicates important contrasts according to the continent of origin. Globally, $53 \%$ are women, due to the predominance of the European population. Among the immigrants from Europe, 56,4 \% are women. This high percentage could be related, on the one hand, to the high degree of feminisation of many of the occupations of these immigrants in the tourism sector. On the other hand, it is linked to the presence of women of advanced age among residential immigrants, due to a differential in life expectancy between men and women. This predominant feminine presence is also registered among immigrants from Latin America, where the percentage of women reaches $57 \%$. This high index is likely related to feminine labour immigration in domestic and personal services and in rare occasions, for its use in prostitution and/or white slave trade nets. Among Asian immigrants a balanced sex composition exists, while men are predominant in African immigration (73\%). Among Moroccans, men represent $76 \%$, while Senegalese men reach $76 \%$ of the total number of Senegalese immigrants.

Much in the same way, differential aspects exist in age group composition according to the foreign immigrants' place of origin (fig. 2). 
Figure 2 : Age and Sex Structure of Foreign Residents, Balearic Islands, June 2001
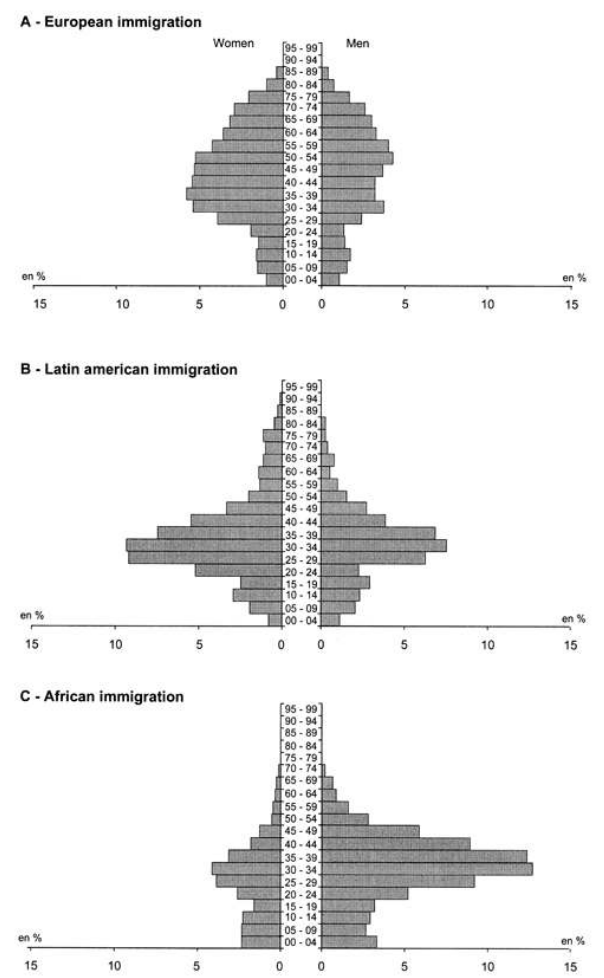

Source : Instituto Nacional de Estadística, Institut Balear d'Estadistica, Salvà-Tomàs.

General highlights per age group:

a) A young adult profile related to a labour immigration is clearly reflected in the curves representing the ages groups of the African and Latin American immigrants (fig. 2 , B et C). The maximum intensities figure in the 25 to 39 age group. They represent one half of the total of these foreign residents. The peak in the 30-34 age group is due to the predominance of young adult labour-related immigration. This group corresponds to a contingent of people that are not registered with official authorities.

b) In contrast with the previous profile are the profiles of immigrants of European origin (fig. 2 A). Their maximum number is distributed among groups of mature adults (from 35-54 years) and persons of advanced age. The present configuration of the profiles of these European immigrants shows a rejuvenation in comparison to previous years. This is due to the escalation in European labour-related immigration. Presently, $25 \%$ of the European residents are over 60 years of age, $36 \%$ are between 40 and 60 and $25 \%$ between 25 and 40 , while the infantile-juvenile population represents $10 \%$. The first group, composed of people of advanced age, corresponds to leisure and rest residents. This group is made up of retired persons, pensioners and pre-pensioners. There are some differences according to nationalities. In the case of the Germans, $30 \%$ are over 60 years old, while $40 \%$ are between 40 and 60 years. A large number of the latter corresponds to an entrepreneurial immigration, consisting of managers, estate agents, directors of service industries and other professionals who maintain their professional activities through tele-working. The presence of the British, however, has registered some changes in relation to the past few years. The British register a smaller presence in persons over 60 years, representing $28 \%$ of the total. The principal cause of this phenomenon is the return of ageing residents their countries of origin, brought on 
by family changes (e.g. one partner is deceased, absence of family in the islands) and / or economic reasons. Regarding the latter, many older British residents have been victims of the rising cost of living in the Balearic Islands, a major factor preventing them from entering private residences.

A typology of recent immigration forms

The economic acceleration the Balearic Islands has experienced in the last twenty years implies a diversification of migratory flows. The Balearic Islands represents a dual migratory model in which migratory flows from advanced countries converge with the immigration phenomena from less developed countries of origin. This implies a diversification of migratory flows and differing motivations among residential and labour-related immigrants. The first case highlights an immigration of European origin, in which residential (retirement migration and leisure / residential migration) and labour-related (labour and managerial immigration) motivations coexist alongside economic and labour-related motivations found in immigration originating from African and Latin American countries.

The Residential Immigration of Europeans

Over the last twenty years, there has been a growing population of foreign origin with motivations unrelated to labour. Their presence and choice of the Balearic Islands as a place of residence, rest and leisure can be explained by a combination of a several causes and motivations. Note several new factors increasing the attractiveness of the Balearic Islands and affecting the entire European area. Among these, we highlight:

31 - The effects of the tourism promotion of the Balearic Islands.

32 - The improved accessibility due to the reduction of binomial time distance (Mallorca is in the isochrone between 1 and 2 hours from the main European airports) and the lower cost of (medium distance) travel.

33 - High availability of flights from the main European airports.

34 - The attraction of the climate and a high number of sun hours.

35 - The perception of the Balearic Islands as a calm and safe destination.

36 - The natural attractiveness and the quality of life.

37 - The attraction of the Mediterranean lifestyle as exponent of a spatial and temporal conception on a human level.

38 The clients interested in these possibilities increase with the progressive ageing of the European population, the state of well-being and the increase in the number of couples without children. These factors have led to an increased mobility in the segments of the European population that include retired persons and pensioners.

39 On the other hand, technological innovations in telecommunications and the development of new forms of work tied to increased flexibility of labour of the "postFordist » or post-modern society have created categories of active people who are able to choose their space and lifestyle freely. These people represent a population segment that is sensitive to these attraction factors. Among them we count tele-workers. These factors have widened the range of typologies of foreign residential immigration:

41 a) Residents of long duration located in areas of tourist specialisation. They form a residential « second home » typology. They make up a significant group whose stay in the islands surpasses one month. They have impacted the real state market through the purchase of apartments and/or second homes located in coastal residential estates far 
from the major areas specialising in tourist hotels and amusement. In many cases they are located near nautical ports in order to combine tranquillity, sun, sea and the practice of nautical sports.

b) Pensioners, pre-pensioners and retirees, permanent and/or seasonal residents of long duration, located in new residential estates and/or rural areas. The latter case represents the formation of a city - countryside flow originating in the main European cities, moving in the direction of the territory of the Balearic Islands. Together, they form a retirement-type migration. More than a quarter of the European immigrants above 60 years of age.

c) Foreign residents whose professional activity is carried out through tele-working. The expansion of new forms of work is due to the introduction of technological innovations in the field of computer science and telecommunications (Internet, mobile and fixed telephony, fax, videoconferences,...). These innovations in the world of the telecommunications allow professionals to do businesses and/or manage companies from their residence without the necessity of continuous work-related commuting.

d) Foreign residents of high economic power who purchase big rural properties and/or urban buildings and monuments of great historical value or of properties located in areas of great landscape value.

This residential foreign immigration has brought about changes in land use models and in real estate market performance. It has accelerated the urbanisation and real estate speculation process, causing a dramatic rise in the prices of urban property and rural land. It has also brought about the emergence of a "ghetto "-type mechanism, transforming the Islands into a sort of residential refuge, isolating the resident foreign population from the insular cultural and territorial identity.

The labour-related immigration of European origin

The effects of tourism promotion on the Balearic Islands have meant a diffusion of information regarding economic opportunities generated by tourism-related activities in addition to the growing number of foreign non-labouring immigrant residents in the islands. The labour market generated by tourism and complementary sectors has brought to the Balearic Islands a large number of foreign immigrants of European origin, attracted by the high potential of business and the demand for services.

This European labour-based immigration forms a complex group, from which we can distinguish three basic typologies of migratory flows:

a) Seasonal labour-related immigration of very short duration (up to 6 months), directly related to the job supply during the high tourist season. It is composed of hardworking and highly mobile employees (employees in hotel chains, entertainers, tourist guides of diverse nationalities, employees in companies that are only active during high season of the tourist activity - pubs, clubs, restaurants, dance halls). It is a difficult group to evaluate quantitatively since some of these people are employed informally, without work contracts.

49 b) Labouring immigrants of long duration that settle in the Islands permanently or for a long duration (more than 6 months). They are composed of professionals and longterm employees in diverse companies, oftentimes managers of foreign origin.

50 c) An entrepreneurial labour-based immigration composed of managers who have established their business in the Balearic Islands. This group is made up of a high number of managers of small and medium-sized firms, including proprietors of bars, 
pubs, clubs and restaurants, proprietors of real state companies, directors of businesses specialising in services to foreigners, managers of complementary service activities, commercial shops and companies of diverse administrative types, among others.

51 These labouring immigrants are mainly concentrated in the city of Palma de Mallorca and in tourist areas. They represent one third of the total number of resident foreigners in the Balearic Islands. They make up a significant proportion of the 30 to 45 age group, representing almost $25 \%$ of the total European foreign population.

The South-North Migratory Labour Flow

The critical economic situation in Africa and Latin America has caused a strong socialdemographic pressure has had a significant impact on the decision to emigrate for a large segment of young adult and/ or less favoured segments of the populations of these regions. The economically dynamic Mediterranean areas of Spain have witnessed an increased presence of new labouring immigrants, especially in the sectors of intensive agriculture, construction and tourism. Since the 1980's, the southern coast of the Mediterranean, as well as Latin American countries, have become departure points of migratory flows toward the north which, in turn, has become an area of migratory attraction. The European Mediterranean forms the southern border of the European Union, where immigrants of extra-European origin form a large concentration (Salvà 1998). The Balearic Islands, which have experienced some of the most dynamic economic growth in Spain, have become a focus of attraction for this new labour-based South-North immigration. The past ten years have seen a constant arrival of immigrant labour from African, Latin American and Asian countries.

This new situation has begun to show its first effects on the characteristics of the population structure of Balearic Islands. Initially, their arrival brought about a rejuvenation of the mean age, as well as a recovery in natality. From an economic perspective, they contribute to the workforce in occupations habitually rejected by the inhabitants of the Balearic Islands. From a social perspective, these communities of labouring immigrants are implicated in a situation of urban heaping, precarious processes, vulnerability and dis-protection. Initially, a clear labour market segmentation of the extra-European labouring immigrants existed. Up to 1995, the most important labour destination for Moroccan immigrants was the sector of intensive irrigated agriculture, especially on Mallorca Island. The Senegalese, on the other hand, were mainly involved in street trading through varied forms of vending in occasional or weekly markets and/or tourist areas. Filipino, Dominican, Peruvian and Colombian women migrants are most frequently employed in domestic service. In the case of Chinese and Asians, only a small minority in the area are managers. The remaining Asians immigrants are frequently employed by managers of their own nationality and they are mainly placed as waiters in Chinese or other « exotic » Asian restaurants. This labour segmentation is beginning to disappear in part, especially in the case of African and Latin American men, because of the increased demand for manpower in the construction industry, where most of the immigrants from Morocco the rest of Africa and Latin America have found work over the last few years. However, these immigrants continue to be largely unregistered (without work or residency permits), occupying jobs in the informal economy, especially in temporary and domestic work and in complementary tourist services. 
the context of family regrouping among African immigrants, immigration is becoming increasingly more feminised. At the same time, migration flows from Latin America show the highest degree of feminisation.

Conclusion

present time, the society residing in the Balearic Islands presents a complex composition. This is the result of the impact of the development of mass tourism that began in the 1950's. Changes have taken place very quickly, creating a process that implies a sensation of social destructuration. The radical change began in the 1950's. This period marked the first steps away from a "ruralita» society toward an « urbanita » society, with all the consequences that derive from such changes. From the perspective of the migratory phenomenon, the development of tourism in the Balearic Islands has had important effects on the evolution of the different migratory models that have developed over the last 40 years.

Firstly, the development of the mass tourism has caused changes in the direction of the migratory movements, transforming the Balearic Islands from emigrant territories into immigration spaces.

57 Secondly, these migratory movements have «changed the rules » of the migratory models, creating the complex situation that we observe at the present time by supplementing the traditional Spanish peninsular with new migratory models. In these new migratory flows, we note an ever increasing presence of foreign immigrants. These latter flows have also undergone changes in type and in origin over the last two decades. From the almost exclusively European residential immigration of leisure and rest, which appeared in the 70's, another type has developed, in which we observe the constantly increasing presence of foreign immigrants of European origin whose motivation for migration is labour. Their attraction to the Balearic Islands appears to be related to the labour market, which is itself tied to the effects of tourism development and to the presence of a significant contingent of non-labouring residents.

The motivations of the residential "holiday-maker "-type foreign immigrant, on the other hand, are not linked to labour. These immigrants perceive the Balearic Islands as a residential refuge. They take into account other important diverse factors such as access to property, accessibility, health services and/or civic security. They have had a significant impact on the insular territorial organisational model, affecting urbanisation and land speculation, as well as in the creation of isolated spaces of segregated socio-cultural characteristics that have redefined the culture and the territory of the Balearic Islands. 


\section{BIBLIOGRAPHIE}

KING Russell (1993), European International Migration 1945-90: A Statistical and Geographical Overview, in Russell King Eds., Mass migration in Europe. The legacy and the future, Chichester, John Wiley\&Sons, pp. 19-39.

MONTANARI Armando and CORTESE Antonio (1993), South to North Migration in a Mediterranean Perspective, in Russell King Eds., Mass migration in Europe. The legacy and the future, Chichester, John Wiley\&Sons, pp. 212-233.

RODRIGUEZ Vicente, SALVÀ Pere and WILLIAMS Allan M.(2001), Northern Europeans and the Mediterranean: a New California or a New Florida, in Russell King, Paolo de Mas and Jan Mansvelt Beck Eds., Geography, Environment and Development in the Mediterranean, Brighton, Sussex Academic Press, pp. 176-195.

SALVÀ TOMÀS Pere (1996), The Balearic Islands: A New «California » for the European People. Paper presented to the $28^{\text {th }}$ International Union Congress, Den Haag, $10 \mathrm{p}$.

SALVÀ TOMÀS Pere (1998), La Méditerranée, frontière entre le Sud et le Nord: les nouveaux courants de migration de l'Afrique méditerranéenne sur le littoral méditerranéen, in Conseil de l'Europe, Conférence Méditerranéenne sur la population, les migrations et le developpement, Strasbourg, Conseil de l'Europe, pp. 261-271.

SALVÀ TOMÀS Pere (2002), Foreign Immigration Flows as Consequence of Tourist Development of the Balearic Islands (Spain), in Michael HALL and Allan M. WILLIAMS, Eds., Tourism and Migration: News relationships between production and consumption Dordrecht-London, Kluwer Academic Publishers, 2001, 13 pp.

WILLIAMS Allan M. and HALL C. Michael (2000), Tourism and migration: New Relationships between Production and Consumption, Tourism Geographies, 2 (1), pp. 5-27.

\section{RÉSUMÉS}

L'objet de cet article est l'analyse des flux migratoires et de leurs effets socio-territoriaux, conséquence du développement touristique des iles Baléares (Espagne). Deux grands types de mouvements migratoires ont été provoqués par la forte spécialisation touristique de ces îles méditerranéennes :

- l'un, de direction Sud-Nord, relève de la migration de main d'œuvre attirée par le dynamisme économique de la région (taux de croissance annuels supérieurs à $6 \%$ ). Les travailleurs viennent d'Afrique (notamment du Maroc) et d'Amérique latine ;

- l'autre, de direction Nord-Sud, a pour origine les pays industriellement avancés d'Europe. Les migrants choisissent les Baléares attirés par le climat, l'accessibilité (fréquence des relations aériennes), les conditions économiques favorables. Ce courant associe trois composantes : une migration résidentielle ayant comme objectif le repos et les loisirs, concernant des personnes âgées, retraitées ou pré-retraitées, une migration de travail liée aux activités de service en direction des touristes et des résidents étrangers, enfin une migration, avec un double objectif, résidence et activité, fondée sur le télé-travail que facilite le haut niveau d'innovation technologique et d'équipement en nouveaux moyens de communication des îles. Cette dernière migration fait des Baléares un laboratoire pour l'analyse en Europe du développement de zones d'activité de type " Nouvelle Californie ". 
The aim of this paper is the analysis of the migratory flows and its social - territorial impacts as consequence of the tourist development in the Balearic Islands (Spain). Its high tourist specialisation has implied the emergence of two big types of migratory flows toward these Mediterranean islands:

- the flow of South to North direction compound for a working migration coming of Africa, Asia and Latin America. The impressive annual economic growth higher to $6 \%$ impels a strong manpower attraction basically compound in the last years for immigrants of Africa (Morocco...) and Latin America;

- the flow of North to South direction with origin in the countries industrially advanced that settles in the Balearic Islands attracted by the favourable climatic conditions, the high accessibility index, the readiness of air flights and the economic advantages.

This flow conforms to triple typology: residential migration, whose objective is the leisure and the rest, conformed for middle-aged and old ages retired and pre-retired, work migration for the services to the tourists and foreign resident communities, The work residential migration based on the teleworking in function of the high-level of technological innovation of the communications in Balearic Islands. These migratory phenomena imply that the Balearic Islands become an analysis laboratory of phenomena type "New California".

Desarrollo turístico y inmigración extranjera en las Islas Baleares. El objeto de este artículo es analizar los flujos migratorios y sus impactos socio-territoriales como consecuencia del desarrollo turístico de las Islas Baleares (España). Su alta especialización turística ha implicado la emergencia de dos grandes tipos de movimientos migratorios a estas islas mediterráneas:

- el flujo de dirección Sur a Norte compuesto por una migración laboral procedente de África, Asia y Latinoamérica. El alto crecimiento económico anual (tasas superiores a $6 \%$ ) se ha convertido en un factor de atracción de mano de obra básicamente compuesta en los últimos años por inmigrantes de Africa (especialmente de Marruecos) y Latinoamérica.

- el flujo de dirección Norte a Sur con origen en los países industrialmente avanzados que eligen a las Islas Baleares atraídos por condiciones climáticas favorables, el alto índice de accesibilidad, la disponibilidad de vuelos aéreos y las ventajas económicas. Este flujo conforma una triple tipología: una migración residencial cuyo objetivo es el ocio y descanso conformada por personas de edades adultas y viejas, retirados y pre-jubilados, una migración laboral ligada a los servicios a turistas y comunidades de residentes extranjeros, una migración laboral residencial basada en el tele-trabajo en función del alto nivel de innovación tecnológica de las comunicaciones en las Islas Baleares. Esta ultima migración implica que las Islas Baleares se conviertan en un laboratorio de análisis del fenómeno tipo "Nueva California".

\section{INDEX}

Mots-clés : flux, tourisme, personnes âgées

Index géographique : Iles Baléares

\section{AUTEUR}

\section{PERE A. SALVÀ-TOMÀS}

Profesor of University, Tourist Research and Documentation Laboratory, University of the Balearic Islands, Campus Universatari. Carretera de Valldemossa, km. 7,5. 07071. PALMA DE

MALLORCA. BALEARIC ISLANDS (SPAIN), Tel. +34.971.173159. Fax : +34.971.173184 